\title{
Chemotherapeutic Treatment of Priapism in Metastatic Rectal Cancer
}

\author{
Y. Kitai H. Takahashi A. Goto H. lida H. Mawatari \\ K. Fujita M. Yoneda M. Inamori Y. Abe N. Kobayashi \\ H. Kirikoshi K. Kubota S. Saito A. Nakajima \\ Gastroenterology Division, Yokohama City University Graduate School of \\ Medicine, Yokohama, Japan
}

\section{Key Words}

Priapism · Metastatic rectal cancer · Chemotherapy

\begin{abstract}
A 65-year-old man was admitted with penile tenderness and dysuria due to priapism. Enhanced computed tomography revealed metastatic tumors in the liver, lung, sacrum and lymph nodes. Advanced rectal cancer, detected by colonoscopy as a primary tumor, was treated with chemotherapy (FOLFOX4). Although the rectal cancer showed no change, five months of chemotherapy improveid the priapism, suggesting that chemotherapy can improve rare symptoms of rectal cancer.
\end{abstract}

\section{Introduction}

Although priapism has been reported as a complication of malignant tumor metastasis, leukemia, sickle cell disease, embolism and spinal canal stenosis [1-5], there are few reports of priapism as a complication of colorectal cancer in the absence of penile metastasis. Here we report a patient with rectal cancer with no penile metastasis in whom chemotherapy resulted in an improvement of priapism.

\section{Case Report}

A 65-year-old man was admitted to our hospital for priapism with tenderness of the penis and dysuria. Enhanced abdominal computed tomography demonstrated metastatic tumors in the liver, lung,

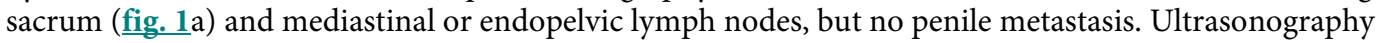
of the penis revealed no tumor and normal blood flow in the penis vessel. Advanced rectal cancer was detected by colonoscopy (fig. 2a). Chemotherapy (FOLFOX4; levofolinate $25 \mathrm{mg}$, fluorouracil $250 \mathrm{mg}$, oxaliplatin $100 \mathrm{mg}$ ) was administered, and although the primary rectal cancer showed no change 


\begin{tabular}{r|l|l|l} 
Case Reports $/ h$ & $\begin{array}{l}\text { Case Rep Gastroenterol 2008;2:505-508 } \\
\text { D0I: 10.1159/000183537 }\end{array}$ & Published online: December 10, 2008 & $\begin{array}{l}\text { O 2008 S. Karger AG, Basel } \\
\text { ISSN 1662-0631 } \\
\text { www.karger.com/crg }\end{array}$ \\
\hline
\end{tabular}

(fig. 2b), sacral metastasis showed slight improvement (fig. 1b), and dysuria and priapism showed obvious improvement after 5 months.

\section{Discussion}

Brain or splenic metastasis and hypercalcemia arising from bone metastasis have been reported as rare complications of colorectal cancer [6-8]. Chemotherapy regimens for metastatic colorectal cancer include fluorouracil, leucovorin, either oxaliplatin or irinotecan, and the VEGF inhibitor bevacizumab [9]. Priapism is a complex involuntary behavioral response that depends on the integration of vascular, endocrine and neurological mechanisms. Stimuli for erection can be classified as psychogenic and reflexogenic [10]. When visceral nerves at the sacrum are stimulated electrically, this results in persistent penile erection. These efferent sacral nerves (S2-S4) are termed 'nervi erigentes'. A second, thoracolumbar erection centre at the level of T12-L1 plays a role in psychogenically mediated erections via sympathetic efferent fibers. Disturbances in penile blood flow due to metastasis in the penis have been reported to cause priapism [11]. In this case, the cause of priapism might have been micrometastasis in the penis, metastatic tumors that affected the spinal cord, or continuous stimulation of nervi erigentes by a metastatic tumor. Chemotherapy, which reduced the metastatic tumor in the sacrum, may also have reduced the level of nervi erigentes stimulation. The results from this case suggest that chemotherapy can be effective for treating rare complications of rectal cancer such as priapism.

Fig. 1. Abdominal computed tomography showing metastatic tumor in sacrum before (a) and after chemotherapy (b).
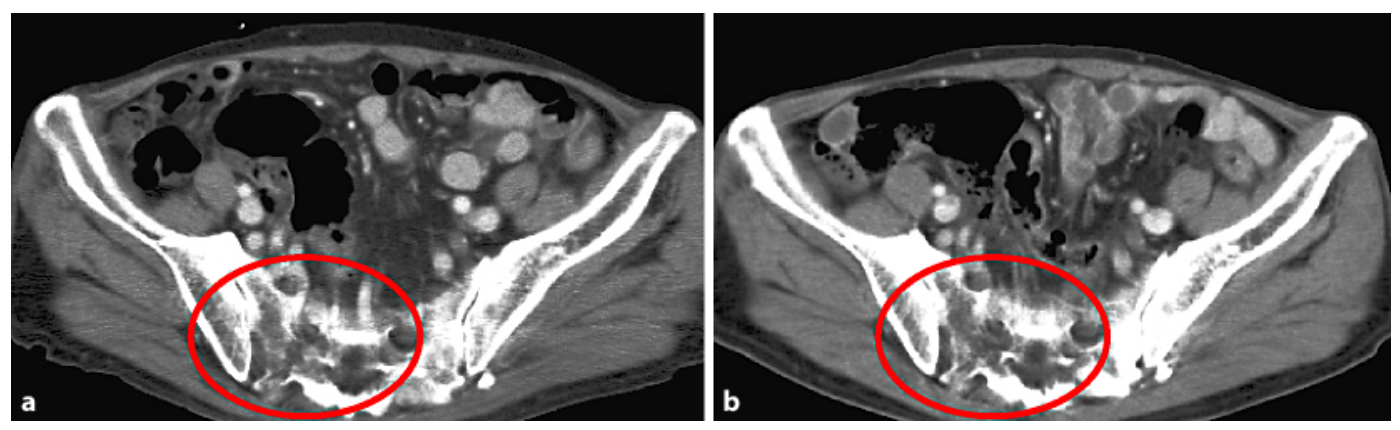


\begin{tabular}{r|l|l|l} 
Case Reports in & $\begin{array}{l}\text { Case Rep Gastroenterol 2008;2:505-508 } \\
\text { D0I: 10.1159/000183537 }\end{array}$ & Published online: December 10, 2008 & $\begin{array}{l}\text { O 2008 S. Karger AG, Basel } \\
\text { ISSN 1662-0631 } \\
\text { www.karger.com/crg }\end{array}$ \\
\hline
\end{tabular}

Fig. 2. Colonoscopy showing type 2 tumor in the rectum before (a) and after chemotherapy (b).

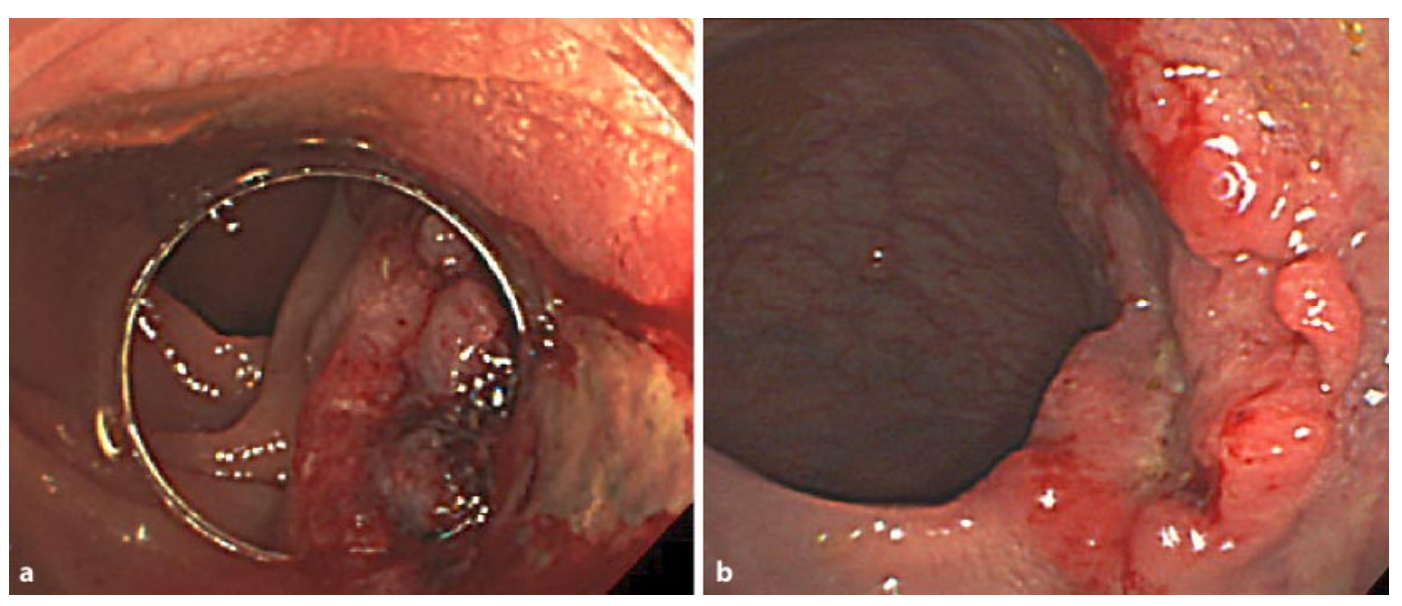




\section{References}

1 Hattori T, Otani T, Ito Y, Takeda H: A report of two cases of priapism with metastatic penile tumor (in Japanese). Nippon Hinyokika Gakkai Zasshi 2002;93:568-572.

-2 Ponniah A, Brown CT, Taylor P: Priapism secondary to leukemia: effective management with prompt leukapheresis. Int J Urol 2004;11:809-810.

-3 Swerdlow PS: Red cell exchange in sickle cell disease. Hematology Am Soc Hematol Educ Program 2006:48-53.

4 Sibai H, Sakoute A, Yaakoubi M, Fehri M: Pediatric priapism associated with pulmonary infection (in French). Ann Urol (Paris) 2003;37:143-145.

-5 Cansever T, Civelek E, Sencer A, Karasu A, Turantan I: Intermittent priapism in degenerative lumbar spinal stenosis: case report. Turk Neurosurg 2007;17:260263.

-6 Gómez Raposo C, Mora Rillo M, Gómez Senent S, Robles Maruhenda A, Montoya F, García Puig J, González Barón M: Brain metastases as the first sign of colon cancer. Clin Transl Oncol 2007;9:742-743.

7 Place RJ: Isolated colon cancer metastasis to the spleen. Am Surg 2001;67:454457.

8 Sakata J, Wakai T, Shirai Y, Sakata E, Hasegawa G, Hatakeyama K: Humoral hypercalcemia complicating adenocarcinoma of the sigmoid colon: report of a case. Surg Today 2005;35:692-695.

9 Sakai Y: Penile metastasis from ascending colon carcinoma: a case report (in Japanese). Hinyokika Kiyo 2001;47:665-667.

10 Weiss HD: The physiology of human penile erection. Ann Int Med 1972;76:793799 .

11 Hecht JR: Current and emerging therapies for metastatic colorectal cancer: applying research findings to clinical practice. Am J Health Syst Pharm 2008;65:S15-S21. 